\title{
Network Interactions in Schistosoma japonicum Infection \\ Identification and Characterization of a Serologically Distinct Immunoregulatory Auto-antiidiotypic Antibody Population
}

G. Richard Olds and Thomas F. Kresina

Divisions of Geographic Medicine and Rheumatology, Departments of Medicine and Pathology, Case Western Reserve University and University Hospitals, Cleveland, Ohio 44106

\begin{abstract}
This study examined the role of naturally occurring anti-idiotypic antibody (anti-id), specific for epitopes on antibodies to schistosome egg antigens (SEA), in serosuppression during Schistosoma japonicum infection. Three anti-id preparations were obtained from pools of infected serum at 12, 16, and 30 wk of infection. Anti-id (12 wk) bound $36 \%$ of labeled anti-SEA antibodies, had an idiotype binding capacity (IBC) of $5 \mu \mathrm{g} / \mathrm{ml}$, and did not suppress SEA-induced proliferation. Anti-id (16 wk) bound $17 \%$ of labeled anti-SEA antibodies, had $29 \mu \mathrm{g} \mathrm{IBC} / \mathrm{ml}$, and reduced ${ }^{3} \mathrm{H}$ incorporation from $21.4 \pm 0.5(10 \mu \mathrm{g} / \mathrm{ml}$ normal Ig) to $9.1 \pm 1.5 \times 10^{4} \mathrm{cpm}(P<0.01)$. Anti-id (30 wk) bound $66 \%$ of labeled anti-SEA antibody, had $84 \mu \mathrm{g} \mathrm{IBC} / \mathrm{ml}$, and suppressed ${ }^{3} \mathrm{H}$ incorporation by $88 \%\left(4.8 \pm 0.3 \times 10^{4} \mathrm{cpm}, P<0.001\right)$. Analysis of the serologic reactivity of these three populations of antiidiotypic antibodies revealed that anti-id (12 wk) described an idiotypic population of anti-SEA molecules containing a minor cross-reactive idiotype ( $\left.\mathrm{SJ}-\mathrm{CRI}_{\mathrm{m}}\right)$. In contrast, anti-id (30 wk) described a serologically distinct, idiotypic population containing a major cross-reactive idiotype of anti-SEA molecules (SJ$\mathrm{CRI}_{M}$ ). A monoclonal anti-id, which reacted with $>50 \%$ of the anti-SEA molecules describing $\mathbf{S J}-\mathbf{C R I}_{\mathbf{M}}$, was profoundly suppressive in vitro and reduced granulomatous inflammation around parasite eggs in vivo from $113 \times 10^{3} \mu \mathrm{m}^{2}$ to $23 \times 10^{3} \mu \mathrm{m}^{2}(80 \%$ suppression, $P<0.001$ ). These observations suggest that immune network interactions modulate inflammation in chronic murine S. japonicum infection.
\end{abstract}

\section{Introduction}

Modulation of granulomatous inflammation occurs during the course of infection in inbred strains of mice. This process results in smaller granulomas around parasite eggs and lower portal pressure (1-4), as well as a decrease in immediate and delayed footpad hypersensitivity reactions to egg antigens $(5,6)$. Furthermore, splenocytes taken from chronically infected animals demonstrate diminished egg antigen-induced proliferative responses (6) and lymphokine production (7). Modulation in mice infected with Schistosoma mansoni is mediated by a suppressor cell cascade involving several well-defined $\mathrm{T}$ cell subpopulations

Address reprint requests to Dr. Olds, Division of Geographic Medicine, Department of Medicine, University Hospitals of Cleveland, Cleveland, OH 44106. 1985

Received for publication 2 April 1985 and in revised form 1 July

J. Clin. Invest.

(C) The American Society for Clinical Investigation, Inc. $0021-9738 / 85 / 12 / 2338 / 10 \quad \$ 1.00$

Volume 76, December 1985, 2338-2347
$(8-12)$, whereas a role for humoral factors is not clear $(13,14)$. In contrast, in Schistosoma japonicum infection, modulation is mediated in part by suppressive serum components $(1,15)$. Adoptive transfer of serum from chronically infected mice reduces the granulomatous inflammation and portal pressure of acutely infected recipient animals (1). In addition, in vitro suppression of soluble egg antigen (SEA) ${ }^{1}$-induced proliferative responses and immunoglobulin synthesis have also been demonstrated (15). The active serum component for both in vivo and in vitro suppression coeluted with $\operatorname{lgG}_{1}(15)$. The present investigation was designed to dissect the molecule(s) responsible for serum-mediated immune modulation observed during chronic infection with $S$. japonicum. The data indicates that both anti-SEA antibodies and anti-idiotypic antibodies (anti-id) mediate this process, but that the latter is a more potent immunosuppressive molecule. In addition, two populations of serologically distinct naturally occurring anti-id populations appear sequentially during infection with $S$. japonicum. Early in the course of infection, anti-id are observed that contain a minor cross-reactive idiotypic population of anti-SEA antibodies. These anti-idiotypic molecules (from acute infection) do not suppress SEA-induced proliferative responses and therefore appear not to be regulatory molecules. A second population of anti-id that describes a major cross-reactive idiotypic population of antiSEA molecules appears during chronic infection. These latter anti-id are antigen combining site-specific and highly suppressive in lymphoproliferation assays. A monoclonal antibody prepared from the fusion of splenocytes from chronically infected animals and with similar serology to the polyclonal anti-id that identifies a major cross-reactive idiotypic population was suppressive both in vitro and in vivo.

\section{Methods}

Animals and infection. C57BL/6 mice (Jackson Laboratories, Bar Harbor, ME) were infected with 25 cercariae of a Philippine strain of S. japonicum at Lowell University, Lowell, MA (provided by a National Institute of Allergy and Immune Diseases supply contract AI-02636). Animals with this intensity of infection undergo modulation after 9-10 wk of infection and survive at least $30 \mathrm{wk}$ (1). To prepare SEA, CF1 mice (Charles River Breeding Laboratories, Cambridge, MA) were infected with 50 cercariae of the same Philippine strain. At 8-12 wk their livers and intestines were removed, and parasite eggs were isolated and processed for antigen (16). Protein concentrations were determined by the method of Lowry et al. (17).

1. Abbreviations used in this paper: anti-id, anti-idiotypic antibody; ELISA, enzyme-linked immunosorbent assay; HP, hybridoma protein; IBC, idiotype binding capacity; R-1, anti-soluble schistosome egg antigen antibody derived from 10-12-wk-infected mouse serum; SEA, soluble schistosome egg antigens; $\mathrm{SJ}_{-} \mathrm{CRI}_{\mathbf{M}}$, major cross-reactive idiotype of antiSEA molecules of Schistosoma japonicum infection; $\mathrm{SJ}_{-\mathrm{CRI}} \mathrm{m}$, minor cross-reactive idiotype of anti-SEA molecules of $S$. japonicum infection. 
Normal and infected C57BL/6 mice were bled from the retroorbital plexus after varying durations of infection, and blood was pooled and allowed to clot overnight at $4^{\circ} \mathrm{C}$. Serum was collected, aliquoted, and then stored at $-70^{\circ} \mathrm{C}$ until used. 28 serum pools from infected mice and 7 serum pools from uninfected animals were used ranging in volume from 1 to $10 \mathrm{ml}$ per pool.

SEA-induced lymphocyte-proliferative assay. C57BL/6 mice infected with $25 S$. japonicum cercariae were killed at $5 \mathrm{wk}$ of infection. Spleens were removed and single cell suspensions were made in RPMI-1640 (KC Biologicals, Lenexa, KS) with 10\% heat-inactivated fetal calf serum (M.A. Bioproducts, Walkersville, MD) supplemented with antibiotics and Lglutamine. Aliquots of $2 \times 10^{5}$ cells in $200 \mu \mathrm{l}$ of media were added to each well of a 96-well microtiter flat-bottomed tissue culture plate (Falcon Plastics, Oxnard; CA). To each well was added $5 \mu \mathrm{g} / \mathrm{ml} \mathrm{SEA} \mathrm{(final} \mathrm{con-}$ centration). Microtiter plates were then incubated for $3 \mathrm{~d}$ in $5 \% \mathrm{CO}_{2}$ at $37^{\circ} \mathrm{C}$. Cultures were pulsed with $1 \mu \mathrm{Ci}$ of tritiated thymidine (New England Nuclear, Boston, MA) $18 \mathrm{~h}$ before the termination of culture and the cells harvested by a semi-automated device. Proliferation was determined by incorporation of tritium by spleen cells (6). Data was expressed as mean counts per minute (cpm) for quadruplicate samples. In some experiments $2 \%(4 \mu \mathrm{l})$ serum or known protein concentrations of purified immunoglobulin suspended in $10 \mu$ l of phosphate-buffered saline (PBS), $\mathrm{pH} 7.2$, were added to cultures just prior to the addition of antigen. Percent suppression is calculated by the following formula: ([cpm control - cpm background] - [cpm experimental - cpm background])/(cpm controi - cpm background) $\times 100$.

Purification of $I g G_{1}$ from mouse serum. Aliquots of serum were chromatographed utilizing a Protein A-bound Sepharose column with a 6- $\mathrm{ml}$ bed volume. The column was equilibrated at $\mathrm{pH}$ 8.0. Mouse IgM, IgA, and nonimmunoglobulin proteins were eluted with $0.1 \mathrm{M}$ sodium citrate, $\mathrm{pH}$ 8.0. Subsequently, $\operatorname{lgG}_{1}, \operatorname{lgG}_{2 \mathrm{a}}$, and $\operatorname{IgG}_{2 \mathrm{~b}}$ were eluted with $0.1 \mathrm{M}$ citrate buffers at $\mathrm{pH} 6.0,4.5$, and 3.5 , respectively (15). Individual immunoglobulin isotype fractions were pooled and concentrated. Purity was then tested by microimmunodiffusion against anti-mouse IgG, IgM, IgA, $\operatorname{IgG}_{1}, \operatorname{lgG}_{2 b}, \operatorname{IgG}_{2 a}$, and $\operatorname{IgG}_{3}$ (Southern Biotechnology, Birmingham, AL) (18).

Anti-SEA enzyme-linked immunosorbent assay (ELISA). $100 \mu \mathrm{l} /$ well of SEA, solubilized in PBS, pH $7.2(10 \mu \mathrm{g} / \mathrm{ml}$ final concentration), was added to each well of a 96-well flexible microtiter plate (Falcon, Microtest III), and incubated overnight at $4^{\circ} \mathrm{C}$ in a humidified box. $12 \mathrm{~h}$ later the plate was shaken to remove the liquid from each well and $175 \mu \mathrm{l}$ of $5 \%$ bovine serum albumin (BSA) (Sigma Chemical Co., St. Louis, MO) in PBS was added. The plate was incubated at $37^{\circ} \mathrm{C}$ for $1 \mathrm{~h}$, washed, and $75-100 \mu \mathrm{l}$ of serum or serum fractions at various dilutions (in PBS) added to each well. The plate was incubated for another $2 \mathrm{~h}$ at $37^{\circ} \mathrm{C}$ and then washed extensively with PBS containing Tween and $0.1 \%$ BSA. Each well then received $75 \mu$ l of a rabbit anti-mouse-alkaline phosphatase conjugate (New England Nuclear, Boston, MA) diluted 1:500 and incubated overnight at room temperature. The next morning the plate was washed five times and $60 \mu \mathrm{l} /$ well of a $1 \mathrm{mg} / \mathrm{ml} p$-nitrophenyl phosphate solution added to each well. Absorbance at $405 \mathrm{~nm}$ was determined in an automated plate reader (MR 580, Dynatech Laboratories, Inc., Alexandria, VA) (19).

Preparation of anti-SEA antibody and normal Ig. Anti-SEA antibody was prepared from either serum or purified $\operatorname{lgG}_{1}$. Anti-egg antibodyenriched and -depleted fractions were prepared by chromatography utilizing a SEA immunoabsorbant column. $1.5 \mathrm{~g}$ of cyanogen bromide (CNBr)-activated Sepharose-4B beads were incubated with $25 \mathrm{mg}$ of SEA. $1 \mathrm{mg}$ of purified $\mathrm{IgG}_{1}$ or $1 \mathrm{~cm}^{3}$ of serum was bound to the Sepharose column in basic buffer $\left(0.1 \mathrm{M} \mathrm{NHCO}_{2}, 0.5 \mathrm{M} \mathrm{NaCl}, \mathrm{pH} 8.3\right)$ and washed. Anti-SEA antibody was then eluted with $0.2 \mathrm{M}$ glycine $\mathrm{HCl}, 0.25 \%$ Non-

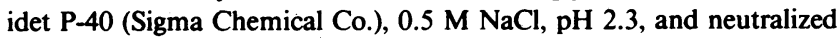
immediately with $0.05 \mathrm{M} \mathrm{NaBorate}(20)$ or eluted with $4 \mathrm{M}$ urea and dialyzed (21). Fractions were concentrated and tested for anti-SEA antibody activity by ELISA. An individual preparation (R-1) of specifically purified anti-SEA antibody derived from pooled serum of mice that were acutely infected (10-12 wk) with 25 cercariae of $S$. japonicum was utilized in the serologic analysis studies.
Absorption of serum with normal mouse Ig and preparation of anti$i d$. Normal mouse Ig was prepared by precipitating $10 \mathrm{ml}$ of normal C57BL/6 serum with $33 \%$ saturated ammonium sulfate, dialysis, and resuspension in PBS, pH 7.2 (22). To remove immunoglobulin with non-idiotypic binding specificities, serum was chromatographed utilizing an immunoabsorbant column prepared by incubating $25 \mathrm{mg}$ of normal mouse serum with $1.5 \mathrm{~g}$ of CNBr-activated Sepharose 4B resin. The eluate was dialyzed and concentrated to the original serum volume by pervaporation (23). Absorbed serum was then chromatographed utilizing a column of $1.5-3.0 \mathrm{mg}$ specifically purified anti-SEA antibody-coupled Sepharose and eluted with $4 \mathrm{M}$ urea, dialyzed, and concentrated. Protein concentrations were determined as before.

Quantification of anti-id activity. Quantitation of anti-id was performed by an indirect method of precipitation as described previously $(24,25)$. In brief, the ${ }^{125} \mathrm{I}$-labeled $(26)$, specifically purified anti-SEA antibody was individually mixed with serial dilutions $(1: 10$ to $1: 20,480)$ of absorbed, specifically purified anti-idiotype preparation. The mixture was incubated for $1 \mathrm{~h}$ at $37^{\circ} \mathrm{C}$. Immune complex precipitation was facilitated by the formation of a carrier precipitate consisting of previously absorbed rabbit anti-ovalbumin and goat anti-rabbit immunoglobulin specific for the Fc fragment of rabbit IgG (24). In addition, each reactive mixture contained $10 \mu \mathrm{g}$ of normal C57BL/6 immunoglobulin to absorb any residual antibody activity directed toward isotypic or allotypic determinants.

The individual reaction mixtures were centrifuged for $10 \mathrm{~min}$ at $3,000 \mathrm{rpm}$ and the supernate was removed. The precipitate was washed with neutral buffer and dissolved in dilute $\mathrm{NaOH}$. The dissolved precipitate and combined supernatants were adjusted to equal volumes and counted separately to determine the fraction of radioactivity precipitated. Data are presented as percent ${ }^{125} \mathrm{I}$-precipitable counts per minute above background levels, which ranged from $2.1-3.8 \%$ total counts per minute.

The idiotype binding capacity (IBC) of serum was derived from the penultimate value on the linear portion of the binding curve (data $p$ $+Y$ ) and the following equation: (microliters of anti-idiotype of data $p$ $+Y) /($ nanograms of anti-SEA antibody at data $p+Y)=1,000 \mu \mathrm{l}$ of sera $\times$ nanograms of anti-SEA antibodies.

Quantitative assays for serologic determinations. Affinity purified anti-idiotypic preparations were radiolabeled with ${ }^{125} I$ (26). Quantitative assays for serologic interactions of the anti-idiotypic preparations derived from different time points in infection were carried out by inhibition in a double-antibody radioimmunoassay (24) in which various amounts of each anti-idiotypic preparation or the antigen (SEA) was tested as an inhibitor. The ligand in this assay was $10 \mathrm{ng}$ of ${ }^{125}$ I-anti-idiotype prepared from $30 \mathrm{wk}$ mouse serum. The ligand was incubated with R-1 (anti-SEA molecules) at limiting conditions as established by the binding curve generated for the $\mathbf{3 0} \mathrm{wk}$ anti-idiotypic preparation and R-1 (described previously). The presence of a serologically identical anti-idiotypic population of molecules in the unlabeled preparation was quantified through its capacity to inhibit binding of the labeled ligand. Inhibitors utilized to compete with 30-wk anti-id binding were 12-wk anti-id, 16-wk antiid, and 30-wk anti-id as well as SEA. The latter inhibition assay determined the percentage of molecules of $30 \mathrm{wk}$ anti-id which were binding site-specific. The data is expressed on a weight basis as the nanograms required for $50 \%$ inhibition of the labeled ligand as well as the percent inhibition of binding of the labeled ligand by $1,000 \mathrm{ng}$ of the unlabeled inhibitor.

Production of monoclonal anti-id. C57BL/6 mice were infected with $S$. japonicum cercariae and were killed at $30 \mathrm{wk}$ of infection. Single-cell suspensions of splenocytes were prepared from infected mice, and erythrocytes were lysed and mixed with $\mathrm{P}_{3} \mathrm{NS} 1$ myeloma cells at a ratio of 10:6 (normal splenocytes/ $\mathrm{P}_{3} \mathrm{NS} 1$ ). Cells were fused with a $50 \%$ solution of polyethylene glycol- 4000 and suspended in supplemented Dulbecco's modified Eagle's medium media (M.A. Bioproducts) containing $10 \mathrm{mM}$ sodium pyruvate, $1 \mathrm{mM}$ Hepes, $200 \mathrm{mM}$ L-glutamine, $10,000 \mathrm{U} / \mathrm{ml}$ penicillin/streptomycin (all Sigma Chemical Co.), and 20\% heat-inactivated fetal calf serum (HyClone Laboratories, Logan, UT) (27). $1 \times 10^{8}$ fused cells were then placed in $6 \times 96-$ microtiter well plates at a volume of $100 \mu \mathrm{l} /$ well and incubated in $5 \% \mathrm{CO}_{2}$ at $37^{\circ} \mathrm{C}$. The next day $100 \mu \mathrm{l}$ 
of media containing hypoxanthine, aminopterin, and thymidine (two times) was added to eliminate unfused $P_{3} N S 1$ cells (27). Supernatants from growing clones were then screened for their ability to suppress SEA-induced proliferation by 5 -wk spleen cells. In addition, supernatants were screened for anti-id activity by co-precipitation, as described previously, using ${ }^{125}$ I-labeled anti-SEA antibody as the labeled ligand. Suppressive clones positive for anti-idiotypic activity were expanded, subjected to three limiting dilutions to assure monoclonality, and injected into pristane-treated F1 (BALB/C $\times$ C57BL/6) mice (28). Monoclonal antibodies are then purified from ascites fluid by ammonium sulfate precipitation (29) and protein concentration determined. The isotype of hybrid-derived antibody was determined on culture supernatants by microimmunodiffusion against isotype-specific rabbit antibodies (30).

Suppression of in vivo granuloma formation: sensitized lung model. Groups of six to eight C57BL/6 mice were injected subcutaneously with $5,000 \mathrm{~S}$. japonicum eggs. $2 \mathrm{wk}$ later one group of mice were given 500 $\mu \mathrm{g}$ of purified anti-idiotypic monoclonal antibodies i.p. Control groups of animals received an equivalent quantity of monoclonal antibodies directed toward an irrelevant noncross-reactive antigen but of the same isotype $\left(\mathrm{IgG}_{1}\right)$. The next day all animals were given 5,000 $\mathrm{S}$. japonicum eggs i.v. $8 \mathrm{~d}$ later all animals were sacrificed, and their lungs were removed and pathologic sections were made (31). The areas around individual $S$ japonicum eggs were measured utilizing a Cambridge model 720 Quantiment Image Analyzer (Cambridge Instruments, Inc., Monsey, NY). 25 granulomas per animal were read and the mean granuloma area was determined. For statistical comparison, the mean of means derived from groups of six to eight animals was used.

\section{Results}

Correlation between suppression of proliferation in vitro and granulomatous inflammation in vivo. Prior to the elucidation of suppressive serum components, experiments were performed to determine the relationship between in vitro suppression of $\left[{ }^{3} \mathrm{H}\right]$ thymidine incorporation by SEA-stimulated splenocytes from acutely infected animals (5-6 wk), and in vivo suppression of granulomatous inflammation after adoptive transfer of various serum pools. 10 separate adoptive transfer experiments (6-10 animals per group) were performed using pools of infected mouse serum. These serum pools were additionally tested for the ability to suppress in vitro blastogenesis. Fig. 1 shows that the ability of a given serum pool to suppress SEA-induced blastogenesis

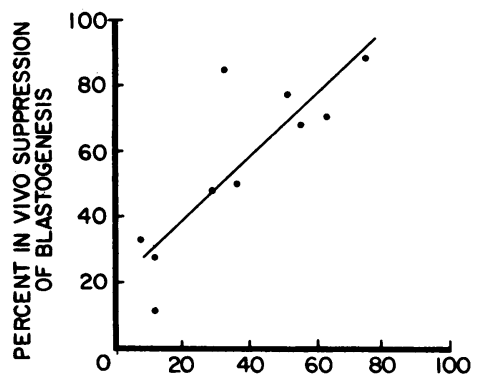

PERCENT IN VIVO SUPPRESSION OF GRANULOMA AREA
Figure 1. Comparison of in vitro suppression of SEAinduced blastogenesis and in vivo suppression of granuloma area by individual serum pools. $2 \%$ infected mouse serum (10-30 wk) was added to $2 \times 10^{5}$ spleen cells from 5-wk-infected mice stimulated with $5 \mu \mathrm{g} /$ $\mathrm{ml} \mathrm{SEA}$, at the beginning of a 72-h culture. Data is expressed as percent suppression of $\left[{ }^{3} \mathrm{H}\right]$ thymidine in-

corporation when compared to normal serum controls. $0.3-0.5 \mathrm{~cm}^{3}$ of these same serum pools was adoptively transferred to acutely infected mice at 4 and $5 \mathrm{wk}$ of infection. Animals were killed at $6 \mathrm{wk}$ and granuloma area around single eosinophilic-staining ova was determined. Data is expressed as percent suppression of granuloma area determined for groups of six to eight mice. Control mice received 0.3$0.5 \mathrm{~cm}^{3}$ of normal mouse serum. The line represents the regression analysis of these points; $r=0.8398, P<0.001$. strongly correlated $r=0.8398(P<0.001)$ with the ability of the same serum pool to suppress granuloma area in vivo in acutely infected recipient mice. In vitro suppression by serum was also observed to increase with duration of infection, $r$ $=0.7098(P<0.01)$ for 28 serum pools tested (data not shown). This in vitro model was, therefore, used to assess the modulatory capacity of infected whole serum pools and subfractions.

Immunosuppressive capacity of anti-SEA molecules. Initial experiments were performed to establish the immunosuppressive capacity of anti-SEA $\operatorname{IgG}_{1}$ molecules. The ELISA titer of antiSEA activity was found to increase with duration of infection. At $5 \mathrm{wk}$, anti-SEA end titers were $1 / 2$ and increased to $1 / 4,096$ for 30-wk serum. Functionally, the anti-SEA antibody subfaction with the highest titerable activity in 30 -wk serum was IgG $_{1}$ $\left(1 / 2,048\right.$ end titer compared with $1 / 4$ for $\operatorname{IgM} / \operatorname{IgA}, 1 / 64$ for $\operatorname{IgG}_{2 a}$ and $1 / 8$ for $\operatorname{IgG}_{2 b} / \operatorname{IgG}_{3}$ ). The $\operatorname{IgG}_{1}$ fraction of several immunosuppressive serum pools was isolated and tested for its ability to suppress SEA-induced proliferative responses (Table I). Concentrations of the IgG $\mathrm{Ig}_{1}$ from 250 to $16 \mu \mathrm{g} / \mathrm{ml}$ (Table I, rows 13) suppressed $\left[{ }^{3} \mathrm{H}\right]$ thymidine uptake in this assay when compared with equivalent protein concentrations of $\mathrm{IgG}_{1}$ prepared from normal C57BL/6 serum. Lesser concentrations of $\operatorname{IgG}_{1}(4.0-0.2$ $\mu \mathrm{g} / \mathrm{ml}$, Table I, rows 4-6) were not suppressive. Also, anti-SEA $\mathrm{IgG}_{1}$ fractions were not observed to influence the background ${ }^{3} \mathrm{H}$ incorporation of unstimulated lymphocytes. The immunosuppressive activity of this immunoglobulin preparation was not a result of repeated column chromatography because $\mathrm{IgG}_{1}$ from normal mouse serum chromatographed utilizing an SEA-coupled Sepharose column was not suppressive.

Anti-id specific for epitopes on anti-SEA molecules. The unusually high $\mathrm{IgG}_{1}$ concentrations of purified anti-SEA antibody needed for in vitro suppression of SEA-induced proliferation led to experiments to determine whether anti-SEA antibody was the only immunosuppressive molecule in infected mouse serum. Anti-SEA antibody enriched and depleted $\mathrm{IgG}_{1}$ fractions were prepared by repeated passage through SEA-bound immunoab-

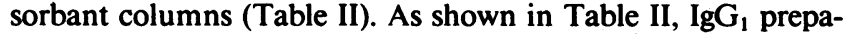
rations depleted of anti-SEA antibody, as shown by end titer ELISA, continued to be immunosuppressive. Three different $\mathrm{IgG}_{1}$ fractions produced $46 \%, 42 \%$, and $58 \%$ suppression of SEAstimulated splenocytes $(100 \mu \mathrm{g} / \mathrm{ml}$ final concentration, Table II, row 2). After absorption of the anti-SEA activity, $\operatorname{IgG}_{1}$ preparations were $77 \%, 90 \%$, and $59 \%$ suppressive at the same protein concentration (Table II, row 3). Anti-SEA $\operatorname{IgG}_{1}$ was purified from the starting $\operatorname{IgG}_{1}$ fraction of infected mouse serum. The approximate yield of specifically purified anti-SEA antibody from $100 \mu \mathrm{g}$ of immunoglobulin was $2-5 \%$. Thus purified anti-SEA antibody was also used at 5 and $10 \mu \mathrm{g} / \mathrm{ml}$ (final concentration). Only at the higher protein concentrations did anti-SEA molecules suppress $\left[{ }^{3} \mathrm{H}\right]$ thymidine uptake. In addition, the anti-SEA antibody did not reconstitute the magnitude of suppression seen with the starting material (Table II, rows 4 and 5). The data derived from these experiments suggested that potent immunosuppressive serum components remained in anti-SEA-adsorbed sera. Subsequent experiments were performed to elucidate these regulatory serum components.

Anti-SEA antibody-depleted serum pools were absorbed to remove isotypic and allotypic determinants by passage over a normal mouse C57BL/6 Ig-coupled Sepharose column, concentrated, and then chromatographed through an anti-SEA antibody-coupled immunoabsorbant column. Serum pools were selected from C57BL/6 mice infected for 12, 16, and 30 wk with 
Table I. Effect of Purified IgG, Anti-SEA on $\left[{ }^{3} \mathrm{H}\right]$ Thymidine Incorporation of Splenocytes from 5-wk-infected Mice*

\begin{tabular}{|c|c|c|c|c|c|}
\hline \multirow[b]{2}{*}{ Concentration } & \multicolumn{2}{|l|}{ Added SEA $\ddagger$} & \multirow[b]{2}{*}{$P \S$} & \multicolumn{2}{|l|}{ No SEA $\ddagger$} \\
\hline & Anti-SEA $\lg _{\mathbf{1}}$ & Normal $\lg _{\mathbf{1}}$ & & Anti-SEA $\operatorname{lgG}_{1}$ & Normal $\lg _{\mathbf{1}}$ \\
\hline$\mu g / m l$ & $c p m \times 10^{\circ} \pm S E M$ & $c p m \times 10^{d} \pm S E M$ & & $c p m \times 10^{4} S E M$ & $c p m \times 10^{4} S E M$ \\
\hline 250.0 & $0.5 \pm 0.1$ & $1.5 \pm 0.1$ & $>0.05$ & $0.3 \pm 0.1$ & $0.3 \pm 0.1$ \\
\hline 63.0 & $1.3 \pm 0.1$ & $3.0 \pm 0.1$ & $>0.01$ & $0.5 \pm 0.1$ & $0.4 \pm 0.1$ \\
\hline 16.0 & $2.2 \pm 0.2$ & $3.4 \pm 0.1$ & $>0.05$ & $0.4 \pm 0.1$ & $0.5 \pm 0.1$ \\
\hline 4.0 & $2.6 \pm 0.2$ & $3.1 \pm 0.1$ & NS & $0.5 \pm 0.1$ & $0.3 \pm 0.1$ \\
\hline 1.0 & $3.3 \pm 0.1$ & $3.0 \pm 0.3$ & NS & $0.4 \pm 0.1$ & $0.4 \pm 0.1$ \\
\hline 0.2 & $3.2 \pm 0.4$ & $3.3 \pm 0.2$ & NS & $0.4 \pm 0.1$ & $0.4 \pm 0.1$ \\
\hline 0 & $3.4 \pm 0.1$ & $3.3 \pm 0.2$ & NS & $0.4 \pm 0.1$ & $0.4 \pm 0.1$ \\
\hline
\end{tabular}

* $2 \times 10^{5}$ splenocytes were cultured for $72 \mathrm{~h}$ in the presence or absence of SEA $(5 \mu \mathrm{g} / \mathrm{ml})$. IgG 1 anti-SEA from infected mouse serum or IgG, from normal C57BL/6 serum was added at the beginning of culture. $¥$ Data expressed as counts per minute $\left[{ }^{3} \mathrm{H}\right]$ thymidine $\times 10^{4}$ for triplicate samples \pm SEM. $\quad \S P$ value estimated by two-sample Student's $t$ test. NS, not significant.

S. japonicum. These serum pools were analyzed for immunosuppressive activity. Reduced $\left[{ }^{3} \mathrm{H}\right]$ thymidine incorporation of $4 \%, 54 \%$, and $83 \%$, respectively (mean of four experiments at $2 \%$ final concentration), was observed for the individual preparations. From these serum pools three anti-id preparations were made and were designated anti-id $12 \mathrm{wk}$, anti-id $16 \mathrm{wk}$, and anti-id $30 \mathrm{wk}$, respectively. To quantitate the amount of anti-id contained in each sample, binding curves were developed using $10 \mathrm{ng}$ of ${ }^{125} \mathrm{I}$-labeled anti-SEA antibody (R-1, prepared from acutely infected serum). The binding curves are shown in Fig. 2. IBC and the maximal percentage of binding to labeled antiSEA antibody was calculated for each anti-id preparation. As shown in Fig. 2, anti-id 12 wk maximally bound an average of $36 \%$ of labeled anti-SEA antibody (mean of two experiments) and was calculated to contain an average of $5 \mu \mathrm{g} \mathrm{IBC} / \mathrm{ml}$. Antiid $16 \mathrm{wk}$, prepared from moderately suppressive serum, maximally bound an average of $17 \%$ of labeled anti-SEA antibody and contained $29 \mu \mathrm{g} \mathrm{IBC} / \mathrm{ml}$. Anti-id $30 \mathrm{wk}$, prepared from highly suppressive serum obtained during chronic infection, maximally bound $66 \%$ of labeled anti-SEA molecules and contained an average of $84 \mu \mathrm{g} \mathrm{IBC} / \mathrm{ml}$. These data quantitating antiid content are summarized in Table III.
Serologic characterization of 30-wk anti-id. Anti-id prepared from 30-wk infected mouse serum describe a idiotypic population of anti-SEA molecules containing a major cross-reactive idiotype $\left(\mathrm{SJ}-\mathrm{CRI} \mathrm{I}_{\mathrm{M}}\right)$ as determined by maximally binding $66 \%$ of labeled anti-SEA molecules (R-1). Alternatively, anti-id 12 wk and 16 wk identify an idiotypic population of molecules describing minor cross reactive idiotypes of anti-SEA antibodies (SJ-CRI $I_{m}$ ) by binding $36 \%$ and $17 \%$ of these molecules, respectively. Competitive inhibition studies were therefore performed with radiolabeled 30 -wk anti-id to establish the serologic relationships (if any) of the various anti-idiotypic population of molecules. In these assays, anti-id $12 \mathrm{wk}$, anti-id $16 \mathrm{wk}$, anti-id $30 \mathrm{wk}$, and SEA were utilized as inhibitors of $\left({ }^{125} \mathrm{I}\right.$-labeled 30 wk anti-id/R-1, anti-SEA antibody) immune complexes. As shown in Table IV, autologous inhibition in the double-antibody radioimmunoassay with anti-id $30 \mathrm{wk}$, showed a total inhibition at 1,000 $\mathrm{ng}$ of inhibitor. A value of $57 \mathrm{ng}$ of unlabeled 30-wk anti-id was required for $50 \%$ inhibition of the (anti-SEA antibodies (R-1)/ ${ }^{125}$ I 30-wk anti-id) immune complexes. Comparatively, when 12-wk anti-id was utilized as an inhibitor, addition to the assay of an excess amount $(1,000 \mathrm{ng})$ was not inhibitory. These data indicate that 30-wk anti-id and 12-wk anti-id describe

Table II. Effects of Depletion of Anti-SEA Antibody from Infected Mouse Serum on the Suppression of SEA-induced Blastogenesis *

\begin{tabular}{|c|c|c|c|c|c|c|c|}
\hline \multirow[b]{2}{*}{ Serum fraction tested } & \multirow{2}{*}{$\begin{array}{l}\text { Protein } \\
\text { concn } \ddagger\end{array}$} & \multicolumn{2}{|l|}{ Experiment 1} & \multicolumn{2}{|l|}{ Experiment 2} & \multicolumn{2}{|l|}{ Experiment 3} \\
\hline & & Anti-SEA§ titer & cpm \pm SEM" & Anti-SEA§ titer & cpm $\pm S E M^{\prime \prime}$ & Anti-SEA§ titer & cpm $\pm S E M^{\prime \prime}$ \\
\hline & $\mu g / m l$ & & & & & & \\
\hline Normal $\operatorname{lgG}_{1}$ & 100 & 0 & $18.9 \pm 0.9$ & 0 & $9.6 \pm 1.0$ & 0 & $11.2 \pm 0.8$ \\
\hline Infected $\operatorname{IgG}_{1}$ & 100 & $1 / 12800$ & $10.6 \pm 0.1(46)$ & $1 / 3200$ & $5.9 \pm 0.3(42)$ & $1 / 300,000$ & $5.5 \pm 0.5(58)$ \\
\hline Infected $\mathrm{IgG}_{1}$ minus anti-SEA & 100 & $1 / 2$ & $5.0 \pm 1.5(77)$ & $1 / 50$ & $1.7 \pm 0.5(90)$ & $1 / 50$ & $4.5 \pm 0.9(59)$ \\
\hline Purified anti-SEA IgG $_{1}$ & 10 & $1 / 800$ & $12.8 \pm 0.7(34)$ & $1 / 200$ & $7.1 \pm 0.4(28)$ & $1 / 100,000$ & $8.1 \pm 0.2(31)$ \\
\hline Purified anti-SEA IgG $_{1}$ & $5 \pi$ & $1 / 400$ & $17.8 \pm 0.4$ & $1 / 100$ & $8.8 \pm 0.4$ & $1 / 50,000$ & $10.1 \pm 0.9$ \\
\hline
\end{tabular}

* $\operatorname{IgG}_{1}$ was purified by passage over Protein A (normal $\operatorname{IgG}_{1}$ or infected $\operatorname{IgG}_{1}$ ). Anti-SEA-enriched (purified anti-SEA IgG I $_{1}$ and depleted (infected $\mathrm{IgG}_{1}$ minus anti-SEA) fractions were prepared by chromatography over SEA bound to CNBr 4B. Fractions were concentrated and protein concentration was determined. Anti-SEA titers were determined by end titer ELISA. Serum fractions were then used to suppress SEA-induced proliferation of splenocytes from $5 \mathrm{wk}$-infected mice. $\ddagger$ Data expressed as $\mu \mathrm{g} / \mathrm{ml}$ final concentration. § Data expressed as last dilution with a significantly different optical density from wells incubated with the same concentration of normal mouse $\operatorname{IgG}_{1}$. "Data expressed as counts per minute tritiated thymidine incorporation \pm SEM for triplicate wells. Parentheses represent percent suppression when compared to normal $\mathrm{IgG}_{1}$; all values at least $P<0.005$. I $5 \mu \mathrm{g}$ represents the approximate yield of anti-SEA obtained from $100 \mu \mathrm{g}$ of $\mathrm{IgG}_{1}$ from infected mouse serum. 


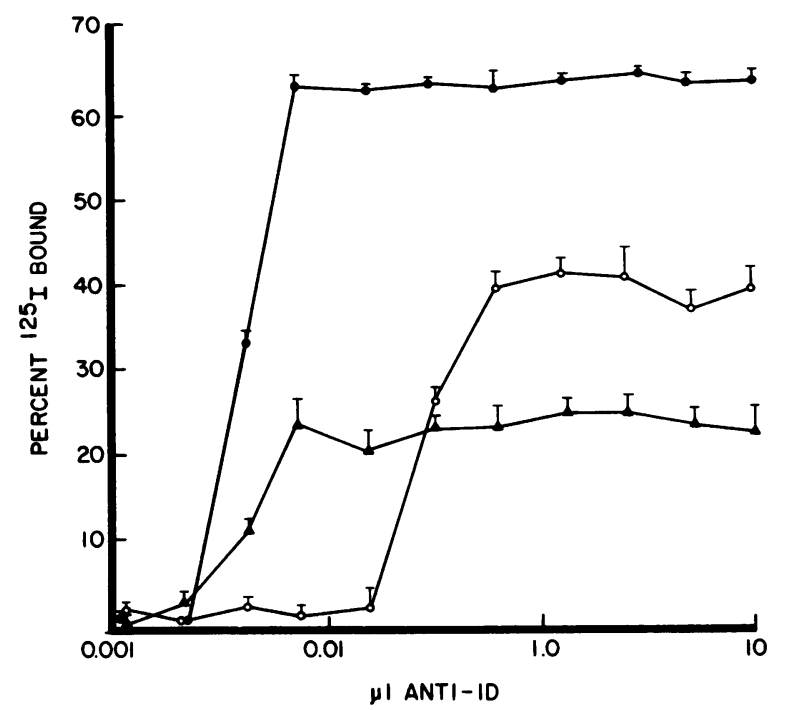

Figure 2. Binding curves of anti-id preparations specific for epitopes on anti-SEA antibodies. Anti-id preparations were prepared from 12 $(0), 16-(\triangle)$ and 30-(๑) wk infected mouse serum and diluted from $1: 10$ to $1: 20,480$ in buffer supplemented with $1 \%$ BSA. The dilutions were individually tested for binding to $10 \mathrm{ng}$ of ${ }^{125} \mathrm{I}$-labeled anti-SEA in the presence of excess normal mouse Ig. Complexes were then precipitated with rabbit immunoglobulin and goat anti-rabbit Fc. Data represents mean percentage of binding of labeled ligand \pm standard error of the mean.

serologically distinct idiotypic populations of anti-SEA molecules. On the other hand, 16-wk anti-id inhibited weakly in the double-antibody assay. $774 \mathrm{ng}$ of 16-wk anti-id were required for $50 \%$ inhibition and 1,000 ng of 16-wk anti-id added to the assay produced $64 \%$ inhibition. These data indicate that molecules comprising 16-wk anti-id bind a portion of the SJ-CRI molecules as described by 30 -wk anti-id.

The addition of SEA as an inhibitor in this assay indicates the percentage of molecules of 30-wk anti-id which are combining site-specific. Addition of 1,000 ng of SEA produced a maximal inhibition of $93 \%$ (Table IV, row 4). Therefore, $93 \%$ of the molecules comprising 30-wk anti-id appeared to be antigencombining site-specific.

Table III. Characterization of Anti-id: Maximal Binding of Anti-SEA, and IBC of Three Different Anti-ids Prepared from Serums of Differing Serosuppressive Activities*

\begin{tabular}{|c|c|c|c|c|}
\hline \multirow[b]{2}{*}{$\begin{array}{l}\text { Anti-id } \\
\text { preparation }\end{array}$} & \multicolumn{2}{|l|}{ Experiment 1} & \multicolumn{2}{|l|}{ Experiment 2} \\
\hline & $\begin{array}{l}\text { \% maximal binding } \\
\text { labeled anti-SEA } \ddagger\end{array}$ & $\mathrm{IBC} / \mathrm{ml}$ & $\begin{array}{l}\text { \% maximal binding } \\
\text { labeled anti-SEA } \ddagger\end{array}$ & $\mathrm{IBC} / \mathrm{ml \S}$ \\
\hline 12 wk & $39 \pm 1$ & 6 & $32 \pm 2$ & 3 \\
\hline $16 \mathrm{wk}$ & $22 \pm 3$ & 31 & $12 \pm 1$ & 26 \\
\hline $30 \mathrm{wk}$ & $64 \pm 1$ & 93 & $67 \pm 2$ & 75 \\
\hline
\end{tabular}

* Anti-id was prepared from 12-, 16-, and 30-wk-infected mouse serum and assayed by binding to ${ }^{125}$ I-labeled anti-SEA in a doubleantibody radioimmunoassay.

$\ddagger$ Mean maximal \% binding \pm SEM of $10 \mathrm{ng}$ of ${ }^{125}$ l labeled anti-SEA for an individual experiment.

$\S \mathrm{IBC} / \mathrm{ml}$ of anti-SEA, determined as described in text.
Table IV. Competitive Inhibition of the Binding of Anti-id 30 wk to Anti-SEA*

\begin{tabular}{lll}
\hline Inhibitor & $\begin{array}{l}\text { Nanograms required for } \\
\text { 50\% inhibition } \neq\end{array}$ & $\begin{array}{l}\text { \% inhibition by } \\
1,000 \text { ng\$ }\end{array}$ \\
\hline 30-wk anti-id & 57 & 97 \\
12-wk anti-id & - & 0 \\
16-wk anti-id & 774 & 64 \\
SEA & 72 & 93
\end{tabular}

* $10 \mathrm{ng}$ of ${ }^{125} \mathrm{I}$-labeled anti-id $30 \mathrm{wk}$ was bound to anti-SEA. The penultimate value for anti-SEA on the linear portion of the binding curve was then used (400 $\mathrm{ng}$ ). Increasing quantities (1-1000 ng) of unlabeled anti-id $12 \mathrm{wk}, 16 \mathrm{wk}, 30 \mathrm{wk}$, and SEA were then added to $400 \mathrm{ng}$ of anti-SEA prior to the addition of labeled anti-id $30 \mathrm{wk}$. Binding was determined by co-precipitation of radioactivity with rabbit Ig and goat anti-rabbit Fc.

¥ Nanograms of sample required for $50 \%$ inhibition of binding determined from binding curves performed in duplicate.

$\S$ Percent inhibition of the binding of labeled ligand to anti-SEA antibody when 1,000 $\mathrm{ng}$ of inhibitor was added.

Immunosuppressive activity of anti-id. Anti-id preparations from 12-, 16-, and 30-wk infected serum showing varying amounts of anti-id content were then tested for their ability to suppress SEA-induced proliferative responses. As shown in Table $\mathrm{V}$, identical protein concentrations $(10 \mu \mathrm{g} / \mathrm{ml})$ of the three antiid populations showed differing immunosuppressive capacity. Anti-id 12 wk was not suppressive in either experiment (Table $\mathrm{V}$, row 3). However, anti-id 16 wk reduced $\left[{ }^{3} \mathrm{H}\right]$ thymidine incorporation compared with control values by approximately half (30-65\% at $10 \mu \mathrm{g} / \mathrm{ml})$ whereas 30 -wk anti-id reduced incorporation by $60-88 \%(10 \mu \mathrm{g} / \mathrm{ml})$ and continued to be suppressive at $5 \mu \mathrm{g} / \mathrm{ml}$ (Table $\mathrm{V}$, rows 4 and 5). A dose-response experiment similar to those performed with purified anti-SEA antibody showed that 30-wk anti-id was suppressive down to a concentration of $0.3 \mu \mathrm{g} / \mathrm{ml}$ (Table VI, rows 1-3). Interestingly, as shown in Table VI, rows 4-6, at very low protein concentrations $(0.08-$ $0.005 \mu \mathrm{g} / \mathrm{ml}$ ) anti-id $30 \mathrm{wk}$ stimulated $\left[{ }^{3} \mathrm{H}\right.$ ] thymidine uptake by 5 -wk-infected splenocytes in the absence of SEA. These data

Table V. Comparative Suppression by Anti-id Preparations and Anti-SEA on $\left[{ }^{3} \mathrm{H}\right]$ Thymidine Incorporation of Splenocytes from 5-wk-infected Mice*

\begin{tabular}{llll}
\hline & & \multicolumn{2}{l}{ Experiment $2 \ddagger$} \\
\cline { 3 - 4 } Inhibitor & $\begin{array}{l}\text { Experiment } 1 \ddagger \\
10 \mu \mathrm{g} / \mathrm{ml}\end{array}$ & $10 \mu \mathrm{g} / \mathrm{ml}$ & $5 \mu \mathrm{g} / \mathrm{ml}$ \\
\hline & $c p m \times 10^{+} S E M$ & $c p m \times 10^{\circ} S E M$ & $c p m \times 10^{4} S E M$ \\
Normal Ig & $21.4 \pm 0.5$ & $18.5 \pm 0.3$ & $16.1 \pm 0.9$ \\
R-1 (anti-SEA) & $21.0 \pm 3.8(\mathrm{NS}) \S$ & $14.2 \pm 1.4(27)$ & $18.1 \pm 1.5(\mathrm{NS})$ \\
12-wk anti-id & $21.5 \pm 5.3(\mathrm{NS})$ & $16.5 \pm 0.9(\mathrm{NS})$ & $16.6 \pm 0.4(\mathrm{NS})$ \\
16-wk anti-id & $9.1 \pm 1.5(65)$ & $13.9 \pm 1.7(30)$ & $14.7 \pm 1.2(\mathrm{NS})$ \\
30-wk anti-id & $4.8 \pm 0.3(88)$ & $9.1 \pm 2.9(60)$ & $6.8 \pm 0.7(67)$ \\
No antigen & $2.9 \pm 0.5$ & $2.8 \pm 1.1$ & $2.2 \pm 0.2$
\end{tabular}

- $2 \times 10^{5}$ splenocytes from 5 wk-infected mice were cultured for $72 \mathrm{~h}$ with or without SEA $(5 \mu \mathrm{g} / \mathrm{ml}$ ). Prior to each incubation, $10 \mu \mathrm{g} / \mathrm{ml}$ or $5 \mu \mathrm{g} / \mathrm{ml}$ (final concentration) of specifically purified anti-SEA or anti-id were added to each well. Control wells received a similar quantity of purified Ig from uninfected mice. $\ddagger$ Data expressed as counts per minute $\times 10^{4} \pm \mathrm{SEM}\left[{ }^{3} \mathrm{H}\right]$ thymidine for triplicate samples.

$\S$ Data in parentheses represent percent suppression when compared to normal Ig controls, all values at least $P<0.05$. NS, not significant. 
Table VI. Effect of 30-wk Anti-id on $\left[{ }^{3} \mathrm{H}\right]$ Thymidine Incorporation of Splenocytes from 5-wk-infected Mice *

\begin{tabular}{|c|c|c|c|c|c|c|}
\hline \multirow[b]{2}{*}{ Concentration } & \multicolumn{2}{|l|}{ Added SEA } & \multirow[b]{2}{*}{$P \S$} & \multicolumn{2}{|l|}{ No SEA } & \multirow[b]{2}{*}{$P$} \\
\hline & 30-wk anti-id & Normal Ig & & 30-wk anti-id & Normal Ig & \\
\hline$\mu g / m l$ & $c p m \times 10^{\circ} \pm S E M$ & $c p m \times 10^{\circ} \pm S E M$ & & $c p m \times 10^{\circ} \pm S E M$ & $c p m \times 10^{\circ} \pm S E M$ & \\
\hline 5.00 & $0.8 \pm .1$ & $4.3 \pm .5$ & $<0.001$ & $1.2 \pm .2$ & $1.2 \pm .2$ & NS \\
\hline 1.25 & $1.6 \pm .2$ & $4.6 \pm .1$ & $<0.001$ & $1.4 \pm .6$ & $1.1 \pm .1$ & NS \\
\hline 0.31 & $3.3 \pm .1$ & $4.7 \pm .2$ & $<0.05$ & $1.4 \pm .1$ & $1.2 \pm .1$ & NS \\
\hline 0.08 & $4.4 \pm .1$ & $4.5 \pm .5$ & NS & $1.9 \pm .1$ & $1.0 \pm .1$ & $<0.05$ \\
\hline 0.02 & $5.7 \pm .6$ & $5.0 \pm .2$ & NS & $2.5 \pm .2$ & $0.7 \pm .2$ & $<0.01$ \\
\hline 0.005 & $6.2 \pm .2$ & $4.9 \pm .1$ & $<0.05$ & $2.6 \pm .1$ & $1.1 \pm .2$ & $<0.01$ \\
\hline 0.001 & $4.9 \pm .7$ & $5.2 \pm .1$ & NS & $1.3 \pm .2$ & $0.8 \pm .2$ & NS \\
\hline 0 & $5.0 \pm .4$ & $5.0 \pm .2$ & NS & $0.9 \pm .1$ & $0.9 \pm .1$ & NS \\
\hline
\end{tabular}

* $2 \times 10^{5}$ splenocytes were cultured for $72 \mathrm{~h}$ in the presence or absence of SEA $(5 \mu \mathrm{g} / \mathrm{ml})$. Various concentrations $(5-0.001 \mu \mathrm{g} / \mathrm{ml}$ final concentration) of 30 -wk anti-id or normal mouse Ig were added at the beginning of culture. $¥$ Data expressed as counts per minute $\left[{ }^{3} \mathrm{H}\right]$ thymidine $\times 10^{4} \pm$ SEM for triplicate samples. $\S P$ value estimated by two-sample Student's $t$ test. NS, not significant.

indicate that under certain conditions anti-id specific for epitopes of anti-SEA molecules can act as an internal image of SEA and stimulate antigen-specific proliferative responses.

Subsequent studies analyzed the in vitro suppressive capacity of both specifically purified anti-id $30 \mathrm{wk}$ and anti-SEA molecules at equal protein concentration. Fig. 3 shows the comparative immunosuppressive activity of 30-wk anti-id and anti-SEA antibody. Anti-id 30-wk antibodies (Fig. $3 \mathrm{~A}$ ) were 1-2 logs more

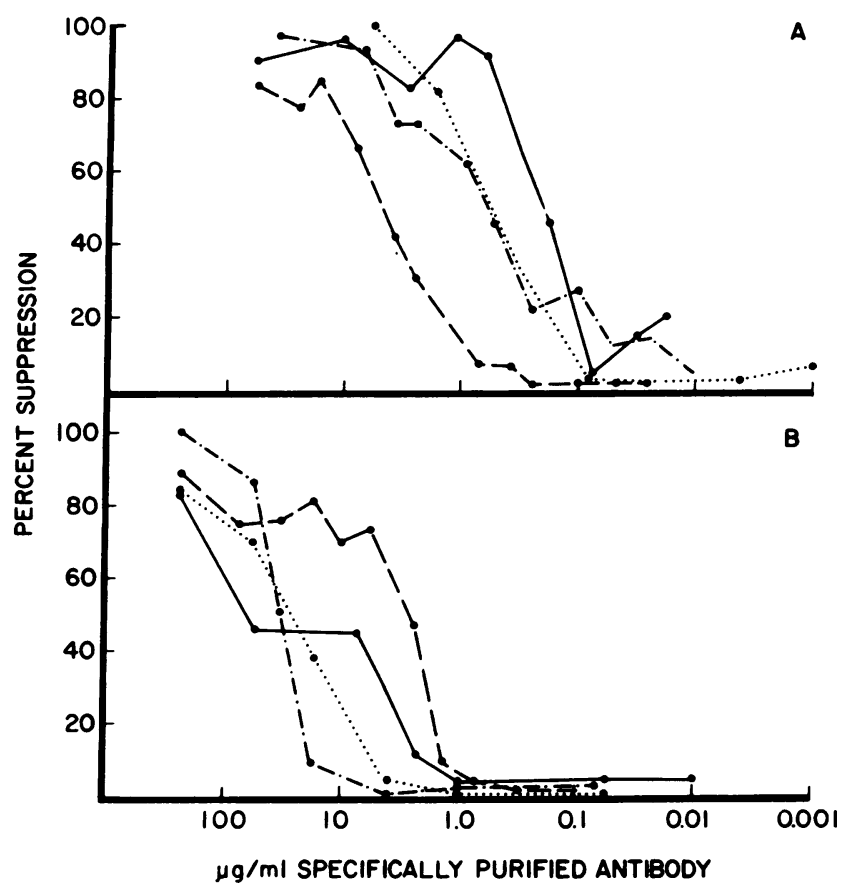

Figure 3. Comparison of suppression of SEA-induced $\left[{ }^{3} \mathrm{H}\right]$ thymidine incorporation by anti-id $(30 \mathrm{wk})$ and anti-SEA. Various protein concentrations of anti-id $30 \mathrm{wk}(A)$ and anti-SEA $(B)$ suspended in $5 \mu \mathrm{l}$ of PBS were added to $2 \times 10^{5}$ spleen cells from 5 wk-infected animals and $5 \mu \mathrm{g} / \mathrm{ml} \mathrm{SEA} \mathrm{(final} \mathrm{concentration)} \mathrm{at} \mathrm{the} \mathrm{beginning} \mathrm{of} \mathrm{a} 72-\mathrm{h}$ culture. Data is expressed as the mean suppression of $\left[{ }^{3} \mathrm{H}\right]$ thymidine incorporation when compared to normal Ig controls. Each line represents an individual experiment. potent than anti-SEA antibodies (Fig. $3 B$ ) with regard to the suppression of SEA-induced incorporation of tritiated thymidine.

Production of a monoclonal antibody with a similar serologic reactivity as 30-wk anti-id (SJ-CRI $I_{M}$ ). Because 30-wk-infected mouse serum contained molecules describing the major crossreactive idiotype $\left(\mathrm{SJ}_{-}-\mathrm{CRI}_{\mathrm{M}}\right)$, we attempted to produce monoclonal antibodies with similar specificities from the fusion of chronically infected mouse spleens with the murine myeloma $P_{3}$ NS1. Several monoclonal antibodies were produced that bound $R-1$ (anti-SEA molecules) in a radioimmunoassay and were immunosuppressive in the SEA-induced proliferative assay. Anti-idiotypic immunosuppressive monoclonal antibodies were then tested for serologic identity with 30 -wk anti-id describing SJ-CRI $\mathrm{M}_{\mathbf{M}}$ by a competitive radioimmunoassay identical to the assay used in Table IV. One clone (100-2E6), characterized serologically, was found to maximally bind $56 \%$ of labeled $\mathrm{R}-1$ anti-SEA antibody and suppress SEA-induced blastogenesis by $91 \%$ at $5 \mu \mathrm{g} / \mathrm{ml}$ final concentration. The comparative serology between 30-wk anti-id and 100-2E6 is shown in Table VII. Hy-

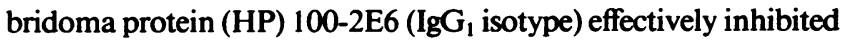
the binding of 30-wk anti-id to R-1 at low quantities of the HP. At very high concentrations of HP 100-2E6, the antibody inhibited the binding of the labeled ligand ( 30 -wk anti-id) by $54 \%$. Thus HP 100-2E6 and 30-wk anti-id recognize a large proportion of similar idiotypic determinants.

Inhibition of granulomatous inflammation by monoclonal anti-id. Monoclonal HP 100-2E6 was prepared from ascites fluid prepared in $\mathrm{F} 1$ animals. $500 \mu \mathrm{g}$ of purified monoclonal 100-2E6 or $500 \mu \mathrm{g}$ of another $\mathrm{IgG}_{1}$ monoclonal raised against a noncross-reactive antigen were purified from ascites and injected i.p. into egg-sensitized C57BL/6 mice. The next day animals were injected i.v. with 5,000 $\mathrm{S}$. japonicum eggs. The subsequent granuloma size around eggs trapped in the pulmonary circulation was determined $8 \mathrm{~d}$ later (31). The average granuloma area in animals who received the isotype control monoclonal was $113 \pm 38 \times 10^{3} \mu \mathrm{m}^{2}$ while the average granuloma size around $S$. japonicum eggs in animals who received HP 100-2E6 was 23 \pm 9 $\times 10^{3} \mu \mathrm{m}^{2}(P=0.00024)$. Therefore, monoclonal HP 100-2E6, which recognized a majority of the idiotypic determinants recognized by 30 -wk anti-id (SJ-CRI $\mathrm{M}_{\mathbf{M}}$ ), was capable of suppressing granulomatous inflammation in vivo. 


\begin{tabular}{|c|c|c|c|c|c|}
\hline & $\begin{array}{l}\text { Immunoglobin } \\
\text { isotype }\end{array}$ & $\begin{array}{l}\text { In vitro suppression of } \\
\text { SEA-induced blastogenesis } \\
(5 \mu \mathrm{g} / \mathrm{ml})^{*}\end{array}$ & $\begin{array}{l}\text { Percent maximum } \\
\text { binding of R-1 } \\
\text { (anti-SEA antibody) } \neq\end{array}$ & $\begin{array}{l}\text { Nanograms required for } \\
50 \% \text { inhibition of } \\
\text { bindings\$ }\end{array}$ & $\begin{array}{l}\text { Percent inhibition } \\
\text { by } 1,000 \mathrm{ng} "\end{array}$ \\
\hline & & $c p m \times 10^{\prime} \pm S E M$ & & & \\
\hline 30-wk anti-id & $\mathrm{IgG}_{1}$ & $96 \pm 4$ & 64 & 57 & 97 \\
\hline $100-2 \mathrm{E} 6$ & $\mathrm{IgG}_{1}$ & $91 \pm 6$ & 56 & 135 & 54 \\
\hline
\end{tabular}

* $2 \times 10^{5}$ splenocytes were cultured for $72 \mathrm{~h}$ with $5 \mu \mathrm{g} / \mathrm{ml} \mathrm{SEA}$. Anti-id was added $(5 \mu \mathrm{g} / \mathrm{ml}$ final concentration) at the beginning of culture. Data is expressed as cpm $\left[{ }^{3} \mathrm{H}\right]$ thymidine $\times 10^{4} \pm$ SEM for triplicate samples. $¥$ Mean maximal percent binding of ${ }^{125} \mathrm{I}$-labeled anti-SEA (R-1). $\S \mathrm{Com}$ petitive inhibition assay as outlined in Methods. Increasing quantities (1-1,000 ng) of unlabeled anti-id (either 30-wk anti-id or 100-2E6) were used to inhibit the binding of ${ }^{125} \mathrm{I}$-labeled 30 -wk anti-id to anti-SEA antibodies (R-1). Binding was determined by co-precipitation of radioactivity with rabbit Ig and goat anti-rabbit Fc. "Inhibition of the binding of labeled 30-wk anti-id to anti-SEA (R-1) antibody when 1,000 ng of inhibitor was added.

\section{Discussion}

The basic pathologic lesion in schistosomiasis is the granulomatous inflammation that occurs around parasite eggs trapped in host tissues (32). In $S$. mansoni and $S$. japonicum infection, this occurs primarily in the liver and results in portal hypertension and bleeding esophageal varices (33). As infection progresses from acute to chronic, an immunologic down-regulation, termed modulation, occurs that results in smaller egg granulomas and lower portal pressures (1-4) and thereby ameliorates clinical disease. The current study reports network interactions in the regulation of inflammation in chronic $S$. japonicum infection. Both naturally occurring antibody to SEA and anti-id, recognizing a subpopulation of anti-SEA molecules, mediate this process in vitro and provide the basis for understanding immune network regulation in schistosomiasis japonica.

The modulation of inflammation and clinical disease has been studied extensively in $S$. mansoni since its original description by Andrade and Warren in 1964 (34). In murine $S$. mansoni this process is mediated by an Lyt $1^{-} 2^{+}, 1-\mathrm{J}^{+}, 1-\mathrm{C}^{+}$cyclophosphamide-sensitive, $T$ suppressor-effector cell $(8,9)$ and Lyt $1^{+} 2^{-}, \mathrm{Ia}^{+}, \mathrm{Qa}-1^{+} \mathrm{T}$ suppressor-inducer cell populations $(10,11)$.

The presumed target of immunosuppression is the $\mathrm{Ly} 1^{+} 2^{-}$ lymphocytes which have been shown in $S$. mansoni to proliferate in response to SEA in vitro (35). A similar finding was found in $S$. japonicum (Olds and Stavitsky, unpublished observation). Using cloned cells the $\mathrm{L}_{3} \mathrm{~T}_{4}{ }^{+}$, Ly $2.2^{-}$phenotype was associated not only with proliferative responses to SEA but lymphokine secretion and in vitro granulomatous responses (36). The role of humoral suppressor factors in regulating immunopathology in mice infected with $S$. mansoni is less clear $(13,14)$. In spite of the biological similarities between $S$. mansoni and $S$. japonicum, several pathologic and immunologic differences have been demonstrated (37-40). Of particular relevance is the observation that the modulatory responses in $S$. japonicum infection appear different. Several strains of inbred mice modulate rapidly after infection with a Philippine strain of $S$. japonicum $(1,41,42)$. Chronically infected animals have lower portal pressures, smaller hepatic egg granulomas and, in C57BL/6 mice, less fibrosis (43). Infected animals rapidly become unresponsive to egg antigens in vivo after footpad inoculation (6), and chronically infected mice form smaller granulomas in the sensitized lung granuloma model (1). In vitro, both SEA-induced lymphocyte-proliferative responses and SEA-induced immunoglobulin synthesis are suppressed after $10 \mathrm{wk}(6)$. Furthermore, we have previously shown that the $\operatorname{IgG}_{1}$ fraction of 30 -wk-infected mouse serum, suppressed granuloma area in the sensitized lung model, portal pressure, and granulomatous inflammation in naturally infected mice in vivo and SEA antigen-specific lymphocyte proliferation and immunoglobulin synthesis in vitro $(1,15)$. Similar experiments performed in $S$. mansoni showed no effect on either parameter $(2,13)$. Recently Cheever et al. (44) have shown that B celldeficient mice, when infected with $S$. japonicum develop larger egg granulomas and more fibrotic liver disease during chronic infection, suggesting a role for immunoglobulin synthesis in immune modulation in murine $S$. japonicum.

The present investigation was designed to dissect the effector molecule(s) responsible for seromediated modulation in murine $S$. japonicum infection. Serosuppression appears to increase with duration of infection, in that there is a positive correlation between the immunosuppressive activity of individual serum pools in vitro and duration of infection. This correlation has been confirmed in vivo (Olds and Stavitsky, manuscript submitted for publication). Such confirmatory in vivo studies, however, require large quantities of reagents $\left(0.3-0.5 \mathrm{~cm}^{3} /\right.$ mouse). The ability of individual serum pools to suppress granulomatous inflammation of acutely infected recipient mice after adoptive transfer correlated with the ability of the same serum pool to suppress SEA-induced proliferative responses in vitro. Thus this latter assay was used to track the purification and characterization of putative suppressive factors.

Initial experiments in the present study suggest that antiSEA antibody is an immunosuppressive component in serummediated modulation in murine $S$. japonicum infection. To this point, Mitchell et al. (45) had shown that some but not all monoclonal anti-SEA antibodies can suppress granulomatous inflammation around eggs in a lung model. R. B. Sidner, D. G. Colley, and C. E. Carter have made a similar observation (personal communication) using a monoclonal antibody to a highly immunostimulatory 140,000 -mol wt glycoprotein antigen of SEA. However, purified anti-SEA IgG $_{1}$ was no more suppressive on a per weight basis than unfractionated $\mathrm{IgG}_{1}$ from 30 -wk mouse serum. In addition, three other observations argued are evidence against anti-SEA antibody as the only immunosuppressive molecule in infected mouse serum: $(a)$ the titer of anti-SEA antibody in individual infected serum pools did not correlate with immunosuppressive activity; $(b)$ anti-SEA anti- 
body purified from minimally suppressive (12 wk) and maximally suppressive ( $30 \mathrm{wk}$ ) serum appeared to be equally effective at similar protein concentrations; $(c)$ serum or $\mathrm{IgG}_{1}$ fractions depleted of most or all of its anti-SEA molecules continued to be suppressive. Because the inhibition of $\operatorname{IgG}_{1}$ is egg antigenspecific (6), we explored the possibility that anti-id directed toward unique epitopes on anti-SEA molecules contributed to immune modulation in vitro.

Three anti-id preparations were made from serum from minimally suppressive serum (12 wk), moderately suppressive serum ( $16 \mathrm{wk}$ ), and profoundly suppressive serum ( $30 \mathrm{wk})$. The anti-id preparations prepared from these sera showed progressively greater in vitro suppressive activity at the same protein concentration. This suppression was found with as little as $\mathbf{0 . 0 1}$ $\mu \mathrm{g} / \mathrm{ml}$ or between 1 and 2 logs lower than the amount of antiSEA antibody required to see a similar effect. At very small protein concentrations $(0.08-0.005 \mu \mathrm{g} / \mathrm{ml})$ anti-id was in fact stimulatory, a similar observation has been made for anti-id in other antigenic systems (46). These preparations contained antiid as demonstrated by the idiotype-specific binding curves generated for each preparation. Of even greater interest was the observation that the serologic specificity of the anti-idiotypic repertoire changed during the course of infection. At $12 \mathrm{wk}$, during the peak of acute infection, the population of anti-id molecules was not suppressive and these antibodies did not crossreact with 30 wk anti-id which was observed to be highly suppressive and serologically distinct from 12-wk anti-id preparation. 16-wk anti-id appeared to cross-react with two thirds of these later suppressive molecules. This suggested that a nonregulatory anti-id develops early in infection and is replaced by a rising titer of a regulatory anti-id.

The observation of two serologically distinct anti-idiotypic populations also describes the idiotypic profile of anti-SEA molecules. In this regard, the present study presents the initial report of a SJ-CRI $I_{M}$ present on a population of anti-SEA molecules. The SJ-CRI $\mathrm{M}_{\mathrm{M}}$ constitutes roughly $66 \%$ of the naturally occurring anti-SEA immune response in infection. In addition, $\mathbf{S J}-\mathrm{CRI}_{\mathrm{m}}$ recognizes roughly $30 \%$ of the anti-SEA response. These data indicate that the anti-SEA immune response observed in $S$. japonicum infection is composed almost exclusively of two serologically distinct cross-reactive idiotypes, $S J-C R I_{M}$ and $S J-C R I_{m}$. In addition, the observation of an immunoregulatory role for antibody directed toward $\mathrm{SJ}-\mathrm{CRI}_{\mathbf{M}}$ is consistent with the notion that major cross-reactive idiotypes serve a regulatory function in the immune response (47).

Further studies were performed to indicate whether these in vitro observations were applicable to the granulomatous inflammation surrounding eggs in vivo. To this point a monoclonal antibody with a similar serologic reactivity to the immunosuppressive polyclonal anti-id preparation was developed. This was necessary because the purification techniques for the preparations of naturally occurring 30-wk anti-id are quite inefficient and thereby preclude in vivo testing. In vivo, HP 100-2E6 reduced granulomatous inflammation around $S$. japonicum eggs by $80 \%$, thus establishing that naturally occurring anti-id that describe major cross-reactive idiotypes in $S$. japonicum infection are immunosuppressive both in vivo and in vitro.

Idiotypic control of the immune response was first suggested by Jerne (48). Anti-id has been shown both to stimulate and to suppress immune responses to several antigens under differing conditions (49-52). In addition, anti-id has been used to stimulate immune responses against several infectious agents in- cluding African trypanosomiasis $(53,54)$, hepatitis B (55), group A streptococci (55), and to occur naturally in mice infected with the mycobacterium BCG $(57,58)$. In this later system, autoanti-id were found to inhibit $T$ cell-mediated hypersensitivity to purified protein derivative (57). In schistosomiasis, Powell and Colley (59) have recently shown that during a murine $S$. mansoni infection anti-id is produced, but naturally occurring anti-id have not been previously described which mediate important pathologic responses to infectious organisms.

It is of interest to note that the regulation of SEA-specific $T$ cell proliferation by anti-id implies that idiotypes are expressed on $T$ cells that are similar or identical to those expressed on immunoglobulins. Numerous data, however, challenge the concept that $T$ cells and $B$ cells carry identical $V_{H}$ regions $(60,61)$. These include the construction of $B$ cell idiotypes utilizing both $V_{H}$ and $V_{L}$ idiotopes, and the restriction of $T$ cell function through the recognition of antigen in the context of self-major histocompatibility complex structures. However, these data do not preclude a serologic relatedness of $\mathrm{T}$ cell membrane structures and B cell-derived immunoglobulin. In this regard, the recent elucidation of the $T$ cell receptor into a heterodimer molecule (62) as well as the report of the T cell receptor chain DNA genomic rearrangements, as reviewed by Robertson (63), indicate that homologous antigenic receptor structures may exist on $T$ cells and B cells. The analogy in structure of the $\beta$-chain of the $T$ cell receptor and heavy chain of immunoglobulin $(62,64)$ suggest that idiotypes derived from $V_{H}$ idiotopes may be particularly relevant in their recognition by $\mathrm{T}$ cell antigenic receptors.

In summary, the present investigation demonstrates that both purified anti-SEA antibody, 30-wk anti-id describing $\mathrm{SJ}_{-}-\mathrm{CRI}_{\mathbf{M}}$ and monoclonal HP 100-2E6 are immunosuppressive to SEAstimulated lymphocytes from acutely infected animals in vitro. Anti-id (30-wk anti-id, 100-2E6) appear to be more potent regulatory molecules on a per weight basis than anti-SEA antibody. In addition, the anti-id repertoire appears to change during the course of infection so that by 30 wk the anti-id population describes a major cross reactive idiotype, is SEA antigen-combining site-specific, and is immunosuppressive. Also, a monoclonal antibody with similar specificities is immunosuppressive in vivo. These studies therefore provide direct evidence for a naturally occurring regulatory network of idiotype and anti-id in murine schistosomiasis japonica.

\section{Acknowledgments}

The authors thank Tracey Bonfield, Charles Carpenter, Pierre Peters, and Candace Finegan for their expert technical assistance and Barbara Jackson for typing the manuscript.

This work was supported by grants AI-15351, AI-18523, and AM20618 from the National Institutes of Health and by the Revco D. S., the Edna McConnell Clark, and the Rockefeller Foundations.

\section{References}

1. Olds, G. R., R. Olveda, J. W. Tracy, and A. A. F. Mahmoud. 1982. Adoptive transfer of modulation of granuloma formation and hepatosplenic disease in murine schistosomiasis japonica by serum from chronically infected mice. J. Immunol. 128:1391-1393.

2. Fanning, M. M., P. A. Peters, R. S. Davis, J. W. Kazura, and A. A. F. Mahmoud. 1981. Immunopathology of murine infection with Schistosoma mansoni: relationship of genetic background to hepatosplenic disease and modulation. J. Infect. Dis. 144:148-153.

3. Colley, D. G., and G. L. Freeman, Jr. 1983. Differences in adult Schistosoma mansoni worm burden requirements for the establishment 
of resistance to reinfection in inbred mice. II. C57BL/KsJ, SWR/J, SJL/J, BALB/cAnN, DBA/2N, A/J, B10.A (3R) and B10.A (5R) mice. Am. J. Trop. Med. Hyg. 32:543-549.

4. Boros, D. L., R. P. Pelley, and K. S. Warren. 1975. Spontaneous modulation of granulomatous hypersensitivity in schistosomiasis mansoni. J. Immunol. 114:1437-1441.

5. Boros, D. L., and K. S. Warren. 1970. Delayed hypersensitivitytype granuloma formation and dermal reaction induced and elicited by a soluble factor isolated from Schistosoma mansoni eggs. J. Exp. Med. 132:488-507.

6. Garb, K. S., A. B. Stavitsky, and A. A. F. Mahmoud. 1981. Dynamics of antigen and mitogen induced responses in murine schistosomiasis japonica: in vitro comparison between hepatic granulomas and splenic cells. J. Immunol. 127:115-120.

7. Boros, D. L., R. P. Pelley, and K. S. Warren. 1975. Spontaneous modulation of granulomatous hypersensitivity in schistosomiasis mansoni. J. Immunol. 114:1437-1441.

8. Colley, D. G., F. A. Lewis, and C. W. Todd. 1979. Adoptive suppression of granuloma formation by $\mathrm{T}$ lymphocytes and by lymphoid cells sensitive to cyclophosphamide. Cell. Immunol. 46:192-194.

9. Chensue, S. W., and D. L. Boros. 1979. Modulation of granulomatous hypersensitivity. I. Characterization of $T$ lymphocytes involved in adoptive suppression of granuloma formation in Schistosoma mansoni infected mice. J. Immunol. 123:1409-1411.

10. Chensue, S. W., S. R. Wellhausen, and D. L. Boros. 1981. Modulation of granulomatous hypersensitivity. II. Participation of Lyl + and Ly2+ T lymphocytes in the suppression of granuloma formation and lymphokine production in Schistosoma mansoni-infected mice. J. Immunol. 127:363-366.

11. Doughty, B. L., and S. M. Phillips. 1982. Delayed hypersensitivity, granuloma formation and modulation around Schistosoma mansoni eggs in vitro. Regulatory T cell subsets. J. Immunol. 128:37-41.

12. Green, W. F., and D. G. Colley. 1981. Modulation of Schistosoma mansoni egg-induced granuloma formation: I-J restriction of $\mathrm{T}$ cell mediated suppression in a chronic parasitic infection. Proc. Natl. Acad. Sci. USA. 78:1151-1154.

13. Colley, D. G. 1976. Adoptive suppression of granuloma formation. J. Exp. Med. 143:696-699.

14. Attallah, A. M., A. H. Smith, K. D. Murrell, T. Fletscher, T. Woody, W. E. Vannier, I. Scher, A. Ahmed, and K. W. Sell. 1979. Characterization of the immunosuppressive state during Schistosoma mansoni infection. J. Immunol. 122:1413-1420.

15. Garb, K. S., A. B. Stavitsky, G. R. Olds, J. W. Tracy, and A. A. F. Mahmoud. 1982. Immune regulation in murine schistosomiasis japonica. Inhibition of in vitro antigen- and mitogen-induced cellular responses by splenocyte culture supernates and by purified fractions from serum of chronically infected mice. J. Immunol. 129:2752-2758.

16. Boros, D. L., and K. S. Warren. 1970. Delayed hypersensitivitytype granuloma formation and dermal reaction induced and elicited by a soluble factor isolated from Schistosoma mansoni eggs. J. Exp. Med. 132:488-507.

17. Lowry, O. H., N. J. Rosebrough, A. L. Farr, and R. J. Randall. 1951. Protein measurement with the folin phenol agent. J. Biol. Chem. 193:154-165.

18. Daniel, T. M., and R. W. Demuth. 1977. Immunochemical analysis of a major antigen of Mycobacterium szulgai. J. Infect. Dis. 135: 778-786.

19. Engvall, E., and P. Perlmann. 1972. Enzyme-linked immunosorbent assay (ELISA). Quantitation of specific antibodies by enzymelabeled anti-immunoglobulin in antigen-coated tubes. J. Immunol. 109: 129-135.

20. Gonyea, L. M. 1977. Purification and iodination of antibody for use in an immunoradiometric assay for serum ferritin. Clin. Chem. 23: 234-236.

21. Daniel, T. M., and P. A. Anderson. 1977. The use of immunoabsorbents for the purification of mycobacterial antigens. J. Lab. Clin. Med. 90:354-360.
22. Daniel, T. M., N. J. Gonchoroff, J. A. Katzmann, and G. R. Olds. 1984. Specificity of Mycobacterium tuberculosis antigen 5 determined with house monoclonal antibodies. Infect. Immun. 45:52-55.

23. Ribi, E., and K. C. Miller. 1967. Methods Immunol. Immunochem. 1:69.

24. Keuttner, M. G., A. L. Wang, and A. Nisonoff. 1972. Quantitative investigations of idiotypic antibodies. I. Idiotypic specificity as a potential genetic marker for the variable regions of mouse immunoglobulin polypeptide chains. J. Exp. Med. 135:579-589.

25. Kresina, T. F., and A. Nisonoff. 1983. Passive transfer of the idiotypically suppressed state by serum from suppressed mice and transfer of suppression from mothers to offspring. J. Exp. Med. 157:15-23.

26. McConalley, J., and F. J. Dixon. 1966. A method of trace iodination of proteins for immunologic studies. Int. Arch. Allergy. 29:185198.

27. Daniel, T., and G. R. Olds. 1985. Demonstration of a shared epitope among mycobacterial antigens using a monoclonal antibody. Clin. Exp. Immunol. 60:249-258.

28. Goding, J. W. 1983. In Monoclonal Antibodies: Principles and Practice. Academic Press, Inc., New York, 100-101.

29. Virgin, H. W., and E. R. Unanue. 1984. Suppression of the immune response to Listeria monocytogenes. I. Immune complexes inhibit resistance. J. Immunol. 133:104-109.

30. Daniel, T. M., and R. W. DeMuth. 1977. Immunochemical analyses of a major antigen of Mycobacterium szulgai. J. Infect. Dis. 135: 778-786.

31. Olds, G. R., and A. A. F. Mahmoud. 1981. Kinetics and mechanisms of pulmonary granuloma formation around Schistosoma japonicum eggs infected into mice. Cell. Immunol. 60:251-260.

32. Warren, K. S. 1980. The relevance of schistosomiasis. N. Engl. J. Med. 303:203-206.

33. Mahmoud, A. A. F. 1984. Schistosomiasis. In Tropical and Geographical Medicine. K. S. Warren and A. A. F. Mahmoud, editors. McGraw Hill Book Co., New York. 433-457.

34. Andrade, Z. A., and K. S. Warren. 1964. Mild prolonged schistosomiasis in mice: alterations in host response with time and the development of portal fibrosis. Trans. R. Soc. Trop. Med. Hyg. 58:53-57.

35. Chensue, S. W., D. L. Boros, and C. S. David. 1980. Regulation of granulomatous inflammation in murine schistosomiasis. In vitro characterization of $\mathrm{T}$ lymphocyte subsets involved in the production and suppression of migration inhibition factor. J. Exp. Med. 151:1398-1403.

36. Lammie, P. J., G. P. Linette, and S. M. Phillips. 1985. Characterization of Schistosoma mansoni antigen-reactive $\mathrm{T}$ cell clones that form granulomas in vitro. J. Immunol. 134:4170-4175.

37. Warren, K. S., D. L. Boros, L. M. Hang, and A. A. F. Mahmoud. 1975. The Schistosoma japonicum egg granuloma. Am. J. Pathol. 80: 279-294.

38. Warren, K. S., and E. O. Domingo. 1970. Granuloma formation around Schistosoma mansoni, $S$. haematobium, and $S$. japonicum eggs in unsensitized and sensitized mice: size and rate of development of cellular composition, cross reactivity and rate of egg destruction. Am. J. Trop. Med. Hyg. 19:292-304.

39. von Lichtenberg, F., D. G. Erickson, and E. H. Sadun. 1973. Comparative histopathology of schistosome granulomas in the hamster. Am. J. Pathol. 72:149-178.

40. Warren, K. S. 1971. Schistosomiasis japonica: models for the pathogenesis of hepatosplenic, intestinal and cerebral disease. Jpn. J. Parasitol. 20:40-44.

41. Warren, K. S., and E. G. Berry. 1972. Induction of hepatosplenic disease by single pairs of Philippine, Kormosan, Japanese and Chinese strains of Schistosoma japonicum. J. Infect. Dis. 126:482-491.

42. Cheever, A. W., R. H. Duvall, and T. A. Hallack, Jr. 1984. Differences in hepatic fibrosis and granuloma size in several strains of mice infected with Schistosoma japonicum. Am. J. Trop. Med. Hyg. 33:602607.

43. Olds, G. R., A. Griffin, and T. F. Kresina. 1985. Dynamics of collagen accumulation and polymorphism in murine Schistosoma japonicum. Gastroenterology. 89:617-624. 
44. Cheever, A. W., J. E. Bryan, S. Hieny, F. von Lichtenberg, M. N. Lunde, and A. Sher. 1985. Immunopathology of Schistosoma japonicum and Schistosoma mansoni infections in B cell-depleted mice. Parasite Immunol. (Oxf.). 7:399-413.

45. Mitchell, G. F., E. G. Garcia, K. M. Cruise, W. V. Tiu, and R. E. Hocking. 1982. Lung granulomatous hypersensitivity to eggs of Schistosoma japonicum in mice analyzed by a radioisotopic assay and effects of hybridoma (idiotype) sensitization. Aust. J. Exp. Biol. Med. Sci. 4:401-416.

46. Eichmann, K. 1978. Expression and function of idiotypes of lymphocytes. Adv. Immunol. 26:195-254.

47. Bona, C., and J. Kearney. 1981. Anti-immunoglobulin antibodies II. Expression of individual and cross-reactive idiotypes on syngeneic and homologous anti-idiotype antibodies. J. Immunol. 127:491-495.

48. Jerne, N. K. 1974. Towards a network theory of the immune system. Ann. Immunol. (Paris). 125c:373-389.

49. Eichmann, K., and K. Rajewsky. 1975. Induction of T and B cell immunity by anti-idiotypic antibody. Eur. J. Immunol. 5:661-667.

50. Cosenza, H., A. Augustin, and M. H. Julius. 1977. Induction and characterization of "autologous" anti-idiotypic antibodies. Eur. $J$. Immunol. 7:273-278.

51. Brown, J. G., and L. S. Rodkey. 1979. Autoregulation of an antibody response via network induced auto-anti-idiotype. J. Exp. Med. 150:67-85.

52. Janeway, C. A. 1981. Manipulation of the immune response by anti-idiotype. In Progress in Immunology IV. M. Foogerean and J. Dausset, editors. Academic Press, Ltd., London. 1150.

53. Sacks, D. L., K. M. Esser, and A. Sher. 1982. Immunization of mice against African trypanosomiasis using anti-idiotypic antibodies. $J$. Exp. Med. 155:1108-1119.

54. Sacks, D. L., and A. Sher. 1983. Evidence that anti-idiotype induced immunity to experimental African trypanosomiasis is genetically restricted and requires recognition of combining site-related idiotypes. J. Immunol. 131:1511-1515.

55. Kennedy, R. C., and G. R. Dreesman. 1984. Enhancement of the immune response to hepatitis B surface antigen. In vivo administration of anti-idiotype induces anti-Hbs that expresses a similar idiotype. J. Exp. Med. 159:655-665.

56. Brils, D. E., C. Forman, S. Hudak, and J. L. Calflon. 1982. Antiphosphorylcholine antibodies of the $T_{15}$ idiotype are optimally protective against streptococcus pneumoniae. J. Exp. Med. 156:1177-1185.

57. Colizzi, B., M. Giuntini, C. Garvelli, M. Caupa, and G. Falcone. 1983. Auto-anti-idiotypic antibodies inhibit $\mathrm{T}$ cell mediated hypersensitivity in BCG infected mice. Cell. Immunol. 80:205-210.

58. Daus, H., H. J. Hammer, K. Rayri, and H. Mauch. 1984. Influence of subclones specific anti-idiotypic antibodies on the kinetics of the immune response to BCG. Immunology. 57:697-702.

59. Powell, M. R., and D. G. Colley. 1985. Demonstration of splenic auto-anti-idiotypic plaque-forming cells in mice infected with Schistosoma mansoni. J. Immunol. 134:4140-4145.

60. Cramer, M., M. Reth, and R. Grutzmann. 1981. T cell $V_{H}$ versus B cell $\mathbf{V}_{\mathrm{H}}$. In Immunoglobulin Idiotypes. C. A. Janeway, E. E. Sercarz, and H. Wigzell, editors. Academic Press, Inc., New York. 429-439.

61. Janeway, C. A., R. E. Core, and F. L. Owen. 1984. T lymphocyte receptors. In Fundamental Immunology. W. E. Paul, editor. Raven Press, New York. 245-266.

62. Hendrick, S. M., E. A. Nielsen, J. Kavgler, D. I. Cohen, and M. M. Davis. 1984. Sequence relationships between putative T cell receptor polypeptides and immunoglobulins. Nature (Lond.). 308:153155.

63. Robertson, M. 1984. Receptor gene rearrangement and ontogeny of T lymphocytes. Nature (Lond.). 311:305-306.

64. Chien, Y., N. R. J. Gascoigne, J. Kavaler, N. E. Lee, and M. M. Davis. 1984. Somatic recombination in a murine $\mathrm{T}$ cell receptor gene. Nature (Lond.). 309:322-325. 